Board's report for 1888 , and the output went on steadily for thirty-four years. He made countless observations and not a few discoveries regarding fishes, their early development and subsequent rate of growth, their migrations and distribution, their habits and their food. Some of his best papers were those in which he demonstrated (in 1895 and later) the cyclonic surface-currents of the North Sea, and the influence of this circulation on the distribution of fish-eggs and young fishes.

Beam-trawling began in Scotland just a little while before Fulton came to the Fishery Board; the otter trawl followed about 1895 , and at once ousted the beam; and the fishermen complained bitterly of the new industry. At first the Board was little in favour of restrictions ; in 1884 it pronounced against a mare clausum, adding, however, that " the true principle is freedom, qualified by such regulations as in the common interest may be found just and necessary". Dr. Fulton's sympathies were all with the line-fishermen; he wished to protect them, and his influence had a deal to do with shaping the policy which closed the Firths of Forth and Clyde and the great area called the Moray Firth. He convinced himself, more than forty years ago, that there had "already been a gradual and considerable diminution of the average catch of Scotch beam-trawlers, per ton of the vessel's tonnage" ; and he said that "it would not be seriously contested that the supply of fish, relative to the machinery of capture, has diminished and is likely to continue to diminish ".

Very difficult questions soon arose out of the closure of the Moray Firth, and helped to turn Fulton's attention to the thorny subject of maritime law. In 1911 he published his magnum opus, on the "Sovereignty of the Sea". The lawyers have not always, I believe, seen eye to eye with him on matters of opinion or interpretation; but the book, obviously and admittedly, is a mine of historical information and curious learning. The earlier chapters, especially those on our troubles with the Dutch in Charles II.'s time, are delightful reading. D'Aroy W. Thompson.

\section{Col. Sir Thomas Holdich, K.C.M.G., K.C.I.E.}

Sir Thomas Hungerford Holdich, who died on Nov. 2 at the advanced age of nearly eightyseven, spent most of his active life in the Survey of India, where he was largely engaged on Frontier and trans-Frontier work. His commission in the Royal Engineers dates so far back as 1862. His first war service was with the Bhutan Expedition in 1865, followed by the Abyssinian campaign in 1867 and the second Afghan War in 1878-80. But his survey career will chiefly be remembered by his work on successive boundary demarcation commissions, and probably he served on more of these than any other office. In 1884 he was with the Russo-Afghan Boundary Commission in connexion with which the once famous, though now almost forgotten, Panjdeh incident took place. As superintendent of frontier surveys he was concerned with the extension of maps on and beyond the Indian frontiers. During this period he was engaged in 1894 on the demarcation of the eastern boundary of Afghanistan, between that country and the frontier tribes. In the following year he was with the Pamir Boundary Commission. Finally, he was appointed chief commissioner for the demarcation of the frontier between Persia and Baluchistan. In 1898 he retired after thirty-six years' service in India.

With such a record it is not surprising that Holdich was appointed, shortly after his retirement, to be a member of the tribunal dealing with the disputed boundary between Argentine and Chile, which had been referred to King Edward as arbitrator. This tribunal, presided over by the late Lord Macnaughton, heard evidence from both sides in London. A stage in the proceedings was reached, however, when it became necessary, through lack of geographical information, that the country in dispute should be inspected. For this purpose Holdich and a party of survey officers visited Chile and the Argentine during the winter of 1901-2. After the additional evidence thus collected had been placed before the tribunal, King Edward gave his award in the autumn of 1902 .

In the meantime, the two countries decided that the actual boundary, as awarded, should be marked out on the ground in the presence of a commission appointed by the British Government. Holdich became chief commissioner for this purpose and again visited South America in the winter of 1902-3. The final settlement of this important boundary, which had been the cause of continuous and dangerous friction between Argentine and Chile, was at last completed. This was one of Holdich's most successful achievements. He possessed in an eminent degree the art of conciliating divergent elements, which gave him a great advantage in dealing with questions of this kind. He had the pen of a ready writer and was also a fluent and pleasant speaker. The excursions which he made into the historical and picturesque aspects of transfrontier exploration were much appreciated. $\mathrm{He}$ was also an admirable artist, and brought back many pictures of the various places he visited.

Holdich's inclinations always seemed to tend. towards the political, artistic, and literary, rather than to the scientific side of life, which did not really interest him. For his various services he was made at different times K.C.M.G., K.C.I.E., C.B., and C.I.E. He served as president of the Royal Geographical Society from 1916 to 1918 , and he was the oldest holder of the Society's gold medal. He was the author of several works, notably "The Indian Borderland ", "The Countries of the King's Award ", and "The Gates of India ".

H. L. C.

\section{Revi. Camillo Melzi d’ Eril.}

Father Camillo Melzi d' Eril, who died on Mar. 10 last, was born on Jan. 6, 1851, and thus at the time of his death was one of our oldest seismologists. He was educated at the Carlo Alberto College, Moncalieri, and later was admitted to the Barnabite Order. In 1873 he joined the teaching 